\title{
Reflective practice and vocational training: theoretical approaches in the field of Health and Nursing
}

\author{
Prática reflexiva e formação profissional: aproximações teóricas no campo da Saúde e da Enfermagem \\ Práctica reflexiva y formación profesional: aproximaciones teóricas en el campo de la Salud y de la \\ Enfermería
}

\section{Luciana Netto ${ }^{1}$ \\ Kênia Lara Silva ${ }^{2}(1)$ \\ Marília dos Santos Rua ${ }^{3}$}

1. Universidade Federal de São João del-Rei.

Campus Divinópolis, MG, Brazil.

2. Universidade Federal de Minas Gerais.

Belo Horizonte, MG, Brazil.

3. Universidade de Aveiro. Aveiro, Portugal.
Corresponding author:

Kênia Lara Silva.

E-mail: kenialara17@gmail.com

Submitted on $10 / 12 / 2017$.

Accepted on 12/14/2017.

DOI: 10.1590/2177-9465-EAN-2017-0309

\begin{abstract}
Objective: Theoretical reflection that uses Reflexivity as a theoretical reference and its objective is to approach Donald Schön's reflective thinking, interrelating it with the innovative curriculum. Method: The writings of Schön and other authors who addressed the themes in their works were used. Results: The innovative curriculum as an expression of dissatisfaction with the fragmentation paradigm may favor reflective practice, since it is necessary to mobilize reflexivity for actions and contexts that are unpredictable in the field of health promotion. Conclusions: The innovative curriculum favors and is favored by a reflective practice and the development of competencies for the promotion of health. Implications for practice: The findings apply to the practice of nurses to deal with the conditioning and determinants of the health-disease process.
\end{abstract}

Keywords: Nursing Philosophy; Health promotion; Curriculum; Problem-Based Learning; Nursing.

\section{Resumo}

Objetivo: Reflexão teórica que utiliza a Reflexividade como referencial teórico e teve por objetivo aproximar o pensamento reflexivo de Donald Schön, interrelacionando-o com o currículo inovador. Método: Foram utilizados escritos de Schön e de outros autores que abordaram os temas em suas obras. Resultados: $\mathrm{O}$ currículo inovador como expressão da insatisfação ao paradigma da fragmentação pode favorecer a prática reflexiva, visto que, no campo da promoção da saúde, é necessário mobilizar a reflexividade para ações e contextos imprevisíveis. Conclusões: $\mathrm{O}$ currículo inovador favorece e é favorecido por uma prática reflexiva e o desenvolvimento de competências para a promoção da saúde. Implicações para a prática: Os achados se aplicam à prática do enfermeiro para lidar com os condicionantes e determinantes do processo saúde-doença.

Palavras-chave: Filosofia em Enfermagem; Promoção da saúde; Currículo; Aprendizagem Baseada em Problemas; Enfermagem.

\section{Resumen}

Objetivo: Reflexión teórica que utiliza la Reflexividad como referencial teórico y que tuvo como objetivo aproximar el pensamiento reflexivo de Donald Schön, interrelacionándolo con o currículo innovador. Método: Fueron utilizados escritos de Schön y de otros autores que abordaron los temas en sus obras. Resultados: El currículo innovador como expresión de la insatisfacción que se tiene sobre el paradigma de la fragmentación puede favorecer la práctica reflexiva, puesto que en el campo de la promoción de la salud, es necesario movilizar la reflexividad sobre acciones y contextos imprevisibles. Conclusiones: El currículo innovador favorece y es favorecido por una práctica reflexiva y el desarrollo de competencias para promover la salud. Implicaciones para la práctica: Los hallazgos se aplican a la práctica del enfermero para lidiar con los condicionantes y determinantes del proceso salud-enfermedad.

Palabras clave: Filosofía en Enfermería; Promoción de la salud; Currículo; Aprendizaje Basado en Problemas; Enfermería. 


\section{INTRODUCTION}

At present, the intentional and apparently uncontrolled expansion of knowledge is experienced. This expansion is due to the advance of technological innovations, the media, economic globalization and new forms of knowledge in people's daily lives. This has provided a series of implications on culture, leisure, education and work, among others, ${ }^{1}$ revolutionizing the day to day, transforming the relationships and forms of communication of the inhabitants of this complex world in which we live. On the other hand, it leads us to a series of problems related to the destiny of mankind. ${ }^{2}$

The changes that have taken place on a global scale in recent decades have generated a globalized, globalizing, complex and innovative society and a new conception of time and relational space, in which it is possible to treat any theme without looking at the whole. Hyperespecialization, common in modern times, reduces the perception of the global, since the themes are fragmented, as well as it softens the sense of solidarity, responsibility and citizenship in the human being. ${ }^{1-3}$

Reductionist thought, conditioned by the Cartesian paradigm, has been culturally determined in human beings, leading them to adopt positions of unconscious control of their way of thinking, knowing and acting. ${ }^{2,4}$ Despite, or due to scientific and technological evolution, what we can observe today is a world marked by technical rationalism. ${ }^{3,5}$ The world lacks a 'thought reform' and hence education, teaching and institutions, including academic training in universities. ${ }^{1}$

This text proposes a reflection on innovative curriculum and reflexive practice as devices for the development of competencies for the promotion of health in the training of nurses. This discussion is justified by the fact that these themes, addressed in an overlapping way, can provide support and theoretical basis for advances in the nursing teaching process.

Studies on differentiated curricular proposals are not recent in the national and international scenarios when approaching the nurses training process. Nevertheless, it is believed that this theme is still tightly emphasized, compromising its applicability in current contexts. Reflexivity is yet little debated in the educational scene, and the majority of the works is centered on a single author, Donald Schön. The development of essential competences for the promotion of health is the most contemporary theme, including the absence of Brazilian production on the subject.

It is assumed that the innovative curriculum as an expression of the dissatisfaction of health professionals' trainers to the fragmentation paradigm, imbued with a heterogeneous and complex entity that is peculiar to it, can favor reflexive practice and the development of competencies for health promotion. This is because, in the health promotion field, it is necessary to mobilize critical reflexivity for complex, unstable and unpredictable actions and contexts. It is necessary to overcome the boundaries between disciplines, to consider uncertainty and contradictions as part of human nature and, in parallel, to use solidarity and individual and collective ethics as a channel for reconnecting beings and knowledge towards the full exercise of citizenship in diversities. ${ }^{6}$

Thus, based on reflective practice in an innovative curriculum, it is expected that, during the academic training process, nursing students will develop competencies to effectively act in health promotion.

\section{REFLECTIVE PRACTICE}

Reflective practice (reflective practicum) can be seen as a specific method of work, whose objective is to allow the professional to produce knowledge based on their professional practice. It is possible to define this method as the "art of intrinsic growth" through reflection, in order to find a solution. ${ }^{1,7}$

American educator Donald Alan Schön (1930-1997) was an influential thinker in the development of the theory and practice of reflective professional learning in the 1980s. For years, he studied reflection on education, with a strong influence from the contributions of the American philosopher John Dewey (1859-1952). His contribution finds strength in this construct by its congruence with complex thinking and its applicability to the innovative curriculum, since reflexivity allows, as much as possible, the intelligibility of the variety of subjects worked simultaneously in life or professional practice, converging sciences, technique and art for the complexity of human condition, leading to autonomy and collective awareness. ${ }^{17,8}$

The author points out that an overly specialized person can become poor in spirit. ${ }^{7}$ Complementing this question, Morin and Perrenoud say that "a well-made head is better than a wellfilled head," while Eliot asks "where did the wisdom we lost in knowledge go?". ${ }^{1}$ The cult of technical rationality, of normative curriculum, of the application of theory and technique, derived from systematic knowledge, preferably scientific, and of the epistemology of practice, besides the separation of teaching, research and practice, still predominant in universities, leave no space for reflexive action and threaten professional competence. ${ }^{7}$

In this sense, Donald Schön proposes a professional formation that interacts with theory and practice, through reflective teaching, based on the process of reflection-in-action, in which learning is privileged through activities and whose ability to reflect be stimulated by the teacher-student interaction, in different practical situations. $^{\text {. }}$

Universities, as formative entities, must behave as regenerating and enriching institutions of cultural heritage. The conservative but uncrystallized university must be able to prepare a future by saving the past. Its predetermined and artificially delimited disciplines and specialties need a broad vision, with an in-depth focus on problems, towards new developments, which transgress the historical boundaries of disciplines. ${ }^{7,9}$

The reform of thought requires the reform of the university, whose focus must fall on the trans and multidisciplinary union around a thematic core systemic organizer that prepares individuals for life. It is a paradigmatic, non-pragmatic reform of 
the context and relational complex. This comprehension is based on the understanding that the knowledge of the whole depends on the knowledge of its parts and vice versa, that phenomena must be seen in their entirety and not in isolation, that one must recognize the dialogicity of realities and respect the difference as uniqueness. . $^{1,7}$,

In order to train reflective professionals it is not necessary to overload them with specific information contingents of the different areas. ${ }^{10} \mathrm{It}$ takes freedom to learn by doing, in a relatively controlled environment, in a dynamic process, "[...] even recognizing that facts, procedures, and theories are static", $7: 31$ and that knowing is an element in movement, changing the phenomena as they are experienced.

Besides knowing in action (know-how), with its roots in the social context, institutionally structured, and reflecting in the action, it is necessary to reflect on the action and, later, to reflect on the reflection in the action to help in the planning and determination of Future actions, to understand future problems and to point out new reasoning and new solutions. ${ }^{4,5,7}$ Therefore, it should be considered that, in uncertain situations, professionals will need to mobilize generic skills, acquired throughout their learning process, recognizing the situation as unique, but being able to apply the experience gained in other experiences, not necessarily identical, but similar, adjusting and adapting to isolated situations. $^{7}$

In the context of professional work there is a constructivist view of the lived reality - "[...] a vision that leads us to see it constructing situations of its practice, not only in professional practice, but also in all other modes of professional competence". 6:39

Based on the human behavior analyzed by Schön, we have contributions of knowledge in the thought that determine the conceptions that mature with the course of life. This knowledge contains residues of information implanted throughout the life by the social, cultural, political, religious, community nucleus, within a complex experiential context that confronts with the scientific data, generating conflict and being able to compromise the reality as it should be evidenced. Thus,

when practitioners respond to undetermined areas of practice by sustaining a reflexive conversation with the materials of their situations, they remake part of their practical world and thus reveal the normally tacit processes of building a world view on which to base their entire practice..$^{7: 39}$

Through this reflexive process, the professional can learn to recognize and apply rules and competences, to reason from their repertoire of experiences, to construct new forms of understanding and action, to change their practice, to reinforce their self-confidence and to develop their self-esteem in an evolutionary continuum process. This reinforces Schön's position ${ }^{7: 97}$ when he states that "when experimentation generates new problems, puzzles and confusions, they can also become material for mutual reflection."
It is necessary to guarantee to the professional the solid, theoretical and practical, and insightful and creative know-how. It is believed that, through the reflective component of dialogue, in relation to what is observed and lived through real practical situations, it is possible to enable the professional to face issues and make appropriate decisions in the face of unstable and complex situations, always new, different, ambiguous and confusing that appear throughout life. 5,7,11 This learning, triggered by experience and this dialogue with the uncertainty that generates knowledge, must be reinforced in the processes of academic formation. ${ }^{1,4}$

It is not without reason that Donald Schön's theory of reflexive practice has gained popularity as an approach to professional development for Nursing and other health and social care professionals, especially since the 1980s. His critique of current normative curricula and technical rationality is an attempt to overcome dualistic thinking regarding professional knowledge and to value the epistemology of practice in the processes of professional competence development. ${ }^{5,12}$

\section{PROFESSIONAL QUALIFICATION}

In Brazil, from the implementation of the Sistema Único de Saúde (SUS - Unified Health System), with the proposed reformulation of the health care model, according to the Basic Operational Standard on Human Resources of the Unified Health System (NOB/RH-SUS) and incentive of the National Health Promotion Policy, ${ }^{13}$ suggestions for curricular reforms and reorientation measures in academic training, with emphasis on health promotion and surveillance, have been taken.

In order to critically and reflexively insert the challenge of the diversity and complexity of the current health system and to act in this context with a view to transforming the health scenario and the labor market itself, a properly trained professional with knowledge, attitudes, technical, ethical and management skills, as well as the commitment to humanization, intersectoriality, interdisciplinarity and integrality of care is essential. ${ }^{5,8}$ In the perspective of the implementation of the National Curricular Guidelines of the courses of the health area, with a focus on health promotion, it is sought to provide training according to the health system, teamwork, integral health care and social demands in force. ${ }^{10,14}$

It is believed that the training process of health professionals should focus on permanent transdisciplinary education and the health education of users, so that they are able to autonomously control their own lives and the community. In this sense, in order to disseminate knowledge about the current paradigms of health and health promotion, a broad expectation falls on the qualification process of professionals working in this area. ${ }^{15}$

As in other scenarios, in Brazil there is still a lack of adequate human resources for health promotion. Special attention is directed to the Nursing undergraduate degree, since the traditional model of decontextualized, content-based, biologistic, reductionist and insufficiently articulated education with health practices has not been able to enable nurses to effectively work in health promotion, one of the structuring axes of the SUS. ${ }^{14}$ 
It is hoped that these shortcomings can be reduced through the implementation of national health and education policies, especially when these strategies are associated with innovative pedagogical structures and curricula in healthy, ethical, stimulating and enjoyable environments with multidisciplinary approaches based on the human, social and biological sciences. ${ }^{14}$

In the present times, the process of professional formation must be mediated by a new curricular matrix capable of escaping from the formative character peculiar to it, built historically and socially throughout the ages..$^{16}$ It is necessary to leave aside the logic of the dichotomy theory-practice, the hierarchization of knowledge and the construction of knowledge that starts from the basic to the applied science and ends with the internship. ${ }^{3}$ It should start with basic, theoretical, propositional and declarative knowledge,$^{5}$ in the selection of appropriate techniques to what one proposes to learn, with emphasis on the interdisciplinary theoretical construction of competences, from the actionreflection integration in practice, in the relationship of dialogue and reciprocal and constructive reflection between teacher and student, in a "formative, constructive, flexible and personal" approach. ${ }^{5}$

In this context of reforms, when the focus of discussion is academic education, there are diverse trends and innovative possibilities for curricula in Brazil and in the world. Among the current curricular innovations, the integrated or interdisciplinary curriculum is seen as a real possibility to the proposal of change that is imperative in thought and in the formative institutions, in the desire to train professionals that respond adequately to the complexity of the problems and the needs of the society in its complexity. $2,16,17$

In the search for effective integration between work and formal education, the proposal of the innovative curriculum emerges. This proposal articulates teaching and service ${ }^{3}$ and integrates theory and practice, in a global, complex and integrative approach to knowledge, ${ }^{2}$ in an attempt to break away and overcome the traditional conceptions of academic teaching, detached from the daily life of professions. In this pedagogical plan, students are responsible for the active and systematic construction of knowledge and values, through successive approximations and advances in the domain of the object of study, and not merely a passive receiver/accumulator of conventional and decontextualized knowledge. ${ }^{3,18-20}$

The design of the innovative curriculum became known through Basil Bernstein's (1924-2000) contributions on educational and curricular policies, thus inspiring proponents such as Maria Cristina Davini, Marise Ramos, Maria Ciavatta and Gaudêncio Frigotto. Scholars of the subject defend the proposal based on methodological, psychological, sociological and epistemological arguments based on "[...] the paradigmatic crisis of science and education based on the fragmentation of knowledge". ${ }^{3}$

Innovative curricula have been used as a form of integral apprehension of knowledge, considering the interdisciplinarity in its construction, leading integration to emphasize the unity between the disciplines and forms of knowledge..$^{3,4}$ In the health area, the dynamic relationships between the fields of knowledge with an interdisciplinary focus, considering multidimensionality, diversity and human complexity, are aspects of the innovative curriculum that result in a flexible, critical, reflective, supportive, democratic, global, independent and transforming profile..$^{2,3}$

The curriculum with innovative characteristics expands the possibilities of knowledge production, favoring the options of solutions to everyday problems of social contexts in which professions develop. ${ }^{3}$ In the meantime, pedagogical advances tend to be limitless both in the intellectual advancement of students, considering their individual characteristics, as in the knowledge of specific reality and elaboration of original theories. ${ }^{3,18-20}$

Results from national and international studies show that curricular innovations are marked by effective teaching-servicemanagement-community integration, which favors the insertion of students in the world of work, leading them to develop a critical and reflexive action, in order to overcome the content-based, biological and preventive paradigm. In this modality of curriculum we identify pedagogical proposals with the use of active teaching-learning methodologies and evaluation methodologies of the permanent education, in order to mediate the construction

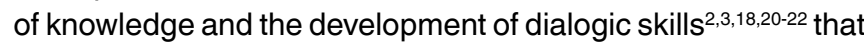
are potential for health promotion.

The conceptual elements of the innovative curriculum are highlighted in contemporary theories, such as complexity ${ }^{22}$ and competence, ${ }^{23}$ through active or problematizing learning methodologies, ${ }^{18,24}$ with an emphasis on the increasing development of autonomy and competence, ${ }^{25}$ stimulating reflection and theorization, based on practice situations, systematic evaluations, solidarity, citizenship and social responsibility to generate internal and external, and individual and collective changes. ${ }^{6}$ These proposals also promote the interlocution between teaching-service and community, through integrative practices articulated to SUS principles towards new paradigms. ${ }^{17}$ Specifically, these elements also stand out in the pedagogical proposals of institutions that train health professionals to work in primary care, with emphasis on SUS. ${ }^{17-19}$

It is necessary to rethink Nursing and Health in a complex perspective, having systemic care and critical reflection as the central focus. At this point, despite the implementation difficulties, it is urgent to articulate and reconnect knowledge and to integrate curricular units within the scope of the courses that prepare the health and nursing professionals to respond to the complexity that characterizes the world today, with its problems and challenges, and to work specifically in the eminently complex health field. In health and nursing education, the concepts of reflexivity and integration are presented as an alternative for the formation of professionals that are more committed to the health reality and its transformation, that is, to act effectively in the proposed model of health care. ${ }^{4}$ 
Finally, in order to elaborate good ideas, it is necessary to guarantee the interdisciplinarity and the connection of the knowledge in the courses ${ }^{2}$ and to have experienced, qualified and self-trained teachers or instructors, as Schön states. ${ }^{7}$ This is also a premise of the innovative curriculum. It is necessary to have teachers with effective communication, who adopt love, art and technique in their professional pedagogical practice, to facilitate learning and to awaken in students the desire to learn, awareness of action and proactivity and, finally, develop their talent, intuition, autonomy, and intellectual, cognitive and creative flexibility in favor of social responsibility and full citizenship. ${ }^{1,5,7}$ This is the only way to train efficient professionals, which are necessary today to produce new knowledge and to develop professions and institutions.

In this heterogeneity of factors imbricated to the formation process, Reflexivity Theory presents itself as a theoretical choice to base curricular innovations that aim at an educational teaching, contextualized knowledge and self-elaborated method that releases, along the walk, ${ }^{3}$ the necessary conditions for a competent action in health promotion.

\section{FINAL CONSIDERATIONS}

This reflection shows that the themes worked throughout the text are important and serve to mark future works in an attempt to deepen their practical applicability in current contexts. It is important to deepen the discussion of these themes in the national context, and especially in the field of nursing training, and it may also be extended to other countries where different formative cultures are observed.

In summary, it can be mentioned that the innovative curriculum, as a device for the development of professional competences, considers the principle of critical reflexivity, of Schönian inspiration, in its base of support and is a promising strategy to potentiate the development of competences for the promotion of health in the training of nurses.

Dialectically, the innovative curriculum favors and is favored by a reflexive practice, considering the complexity of the situations, dynamics understood as stimulating the development of essential competences for the promotion of health in the training of nurses. This reflexive practice enables nurses to deal critically with the conditioning and determinants of the health-disease process and to carry out their practices with autonomy, within an expanded vision of integral health, focusing on the environment and citizenship, stimulating the protagonism of the subjects, the co-responsibility between them, the formation of solidarity bonds and the collective participation in health practices. These values, essential to nursing practice, coincide with the values that guide the National Policy for Health Promotion.

In conclusion, it is suggested to deepen the research theme, mainly through the identification of the appropriation of these concepts by the actors involved and/or directly related to the nurses training process, which should be evidenced by exploratory studies and field work.

\section{REFERENCES}

1. Morin E. A cabeça bem feita: repensar a reforma: reformar o pensamento 21a ed. Rio de Janeiro: Bertrand Brasil; 2014. 128 p.

2. Velloso MP, Guimarães MBL, Cruz CRR, Neves TCC. Interdisciplinarity and training in the collective health area. Trab Educ Saúde [Internet]. 2016 Jan/Mar; [cited 2018 Jan 16]; 14(1):257-71. Available from: http://www.scielo.br/scielo.php?script=sci_arttext\&pid =S1981-77462016000100257

3. Keller-Franco E, Kuntze TD, Costa LSD. Curricular innovation in health professsionals formation. Rev e-Curriculum (São Paulo) [Internet]. 2012 Aug; [cited 2018 Jan 16]; 8(2):1-14. Available from: http:// www.uel.br/graduacao/odontologia/portal/pages/arquivos/NDE/ INOVAÇÃO\%20CURRICULAR\%20NA\%20FORMAÇÃO\%20DOS\%20 PROFISSIONAIS\%20DA\%20SAÚDE.pdf

4. Santos SSC, Hammerschmidt KSA. Complexity and the reconnection of interdisciplinary knowledge: contribution of Edgar Morin's thoughts. Rev Bras Enferm [Internet]. 2012 July/Aug; [cited 2018 Jan 16]; 65(4):561-5. Available from: http://www.scielo.br/scielo.php?script=sci_arttext\&pid =S0034-71672012000400002

5. Alarcão I. Reflexão crítica sobre o pensamento de D. Schön e os programas de formação de professores. Rev Fac Educ [Internet]. 1996 Jul/Dec; [cited 2018 Jan 16]; 22(2):11-42. Available from: http://www. revistas.usp.br/rfe/article/view/33577

6. Dalla Lana L, Arend Birner J. Um relato de caso sobre a construção e elaboração do portfólio como metodologia avaliativa de aprendizagem. Cienc Enferm [Internet]. 2015; [cited 2018 Jan 16]; 21(3):10112. Available from: http://www.scielo.cl/scielo.php?pid=S071795532015000300009\&script=sci_abstract\&tlng=pt

7. Schön DA. Educando o profissional reflexivo: um novo design para o ensino e a aprendizagem. Porto Alegre: Artmed; 2000.

8. Dillenburg JD, Caetano MR. Pedagogical supervision promoting reflexive practice as an instrument to train teaches in early childhood education. Rev Acadêmica Licencia\&acturas [Internet]. 2016; [cited 2018 Jan 17]; 4(1):98-107. Available from: http://www.ieduc.org.br/ojs/index.php/ licenciaeacturas/article/view/105

9. Morin E. Introdução ao pensamento complexo. 3a ed. Porto Alegre: Sulina; 2007.

10. Schön DA. Educating the reflective practioner. San Francisco: JosseyBass; 1987.

11. Kinsella EA. Professional knowledge and the epistemology of reflective practice. Nurs Philos [Internet]. 2010 Jan; [cited 2018 Jan 16]; 11(1):3-14. Available from: https://www.ncbi.nlm.nih.gov/pubmed/20017878

12. Ministério da Saúde (BR). Secretaria de Vigilância em Saúde. Secretaria de Atenção à Saúde. Política Nacional de Promoção da Saúde (PNPS) Revisão da Portaria MS/GM № 687, de 30 de março de 2006. Brasília DF: Ministério da Saúde; 2014.

13. Pereira L, Lopes M, Lugarinho R. Diretrizes curriculares nacionais e níveis de atenção à saúde: como compatibilizar? VII Congresso Nacional da Rede Unida;2006 Jul 15-18; Curitiba, PR, Brazil [Internet]. [cited 2018 Jan 16]. Available from: http://www.fnepas.org.br/pdf/termo_oficina1.pdf

14. Chiesa AM, Nascimento DDG, Braccialli LAD, Oliveira MAC, Ciampone MHT. Health professionals' education: a significant learning guides by health promotion. Cogitare Enferm [Internet]. 2007 Apr/Jun; [cited 2018 Jan 16]; 12(2):236-40. Available from: http://revistas.ufpr.br/cogitare/ article/view/9829/6740

15. Heidmann ITSB, Almeida MCP, Boehs AE, Wosny AM, Monticelli M Promoção à saúde: trajetória histórica de suas concepções. Texto Context Enferm [Internet]. 2006 Apr/Jun; [cited 2018 Jan 16]; 15(2):3528. Available from: http://www.scielo.br/scielo.php?script=sci_arttext\&pi $\mathrm{d}=$ S0104-07072006000200021

16. Braid LMC, Machado MFAS, Aranha AC. State of the art of curriculum research relating to healthcare professional training courses: a survey on articles published between 2005 and 2011. Interface (Botucatu) [Internet]. 2012 Jul/Sep; [cited 2018 Jan 16]; 16(42):679-92. Available from: http://www.scielo.br/scielo.php?script=sci_arttext\&pid $=$ S1414-32832012000300008 
17. Alves MNT, Marx M, Bezerra MMM, Landim JMM. Pedagogica Methodologies Active in Health Education. Id Line Multidiscip Psychol J Artig [Internet]. 2017 Jan; [cited 2018 Jan 16]; 33(Supl. 2):339-46. Available from: https://idonline.emnuvens.com.br/id/article/ download/659/927

18. Anjos DRL, Aguilar-da-Silva RH. Academic Experiences Questionnaire (QVA-R): medical students evaluation in an innovative resume course. Avaliação (Campinas) [Internet]. 2017 Jan/Apr; [cited 2018 Jan 16]; 22(1):105-23. Available from: http://www.scielo.br/scielo. php?script=sci_arttext\&pid=S1414-40772017000100105

19. Lima VV. Constructivist spiral: an active learning methodology. Interface (Botucatu) [Internet]. 2017 Apr/Jun; [cited 2018 Jan 16]; 21(61):42134. Available from: http://www.scielo.br/scielo.php?script=sci_ arttext\&pid=S1414-32832017000200421\&lng=en\&tlng=en

20. Fertonani HP, Pires DEP, Biff D, Scherer MDA. The health care model: concepts and challenges for primary health care in Brazil. Ciênc Saúde Coletiva [Internet]. 2015 Jun; [cited 2015 Sep 15]; 20(6):186978. Available from: http://www.scielo.br/scielo.php?script=sci arttext\&pid=S1413-81232015000601869\&Ing=en\&nrm=iso\&tlng=en

21. .Simon E, Jezine E, Vasconcelos EM, Ribeiro KSQS. Active teachinglearning methodologies and popular education: agreements and disagreements in the context of health professionals' education.
Interface (Botucatu) [Internet]. 2014; [cited 2018 Jan 16]; 18(Suppl. 2):1355-64. Available from: $\mathrm{http}: / / \mathrm{www}$. scielo.br/scielo.php?script=sci_ arttext\&pid=S1414-32832014000601355

22. Costa JRB, Romano VF, Costa RR, Gomes AP, Siqueira-Batista R Active teaching-learning methodologies: medical students' views of problem-based learning. Rev Bras Educ Med [Internet]. $2011 \mathrm{Jan} / \mathrm{Mar}$; [cited 2018 Jan 16]; 35(1):13-9. Available from: http://www.scielo.br/ scielo.php?script=sci_arttext\&pid=S0100-55022011000100003

23. Lima VV. Competência: distintas abordagens e implicações na formação de profissionais de saúde. Interface (Botucatu) [Internet]. 2005; [cited 2018 Jan 16]; 9(17):369-79. Available from: http://www. scielo.br/scielo.php?pid=S1414-32832005000200012\&script=sci_ abstract\&tIng=pt

24. Carvalho AT, Almeida ER, Jaime PC. Health conditionalities in the Bolsa Família program - Brazil: an analysis through health professionals. Saúde Soc [Internet]. 2014 Oct/Dec; [cited 2018 Jan 16]; 23(4):137082. Available from: http://www.scielo.br/scielo.php?script=sci_arttext\& pid=S0104-12902014000401370

25. Silva MJ, Sousa EM, Freitas CL. Nursing education: interface between the curriculum guidelines and content of primary health attention. Rev Bras Enferm [Internet]. 2011 Mar/Apr; [cited 2018 Jan 16];64(2):315-21. Available from: http://www.scielo.br/scielo.php?script=sci_arttext\&pid $=$ S0034-71672011000200015 